\title{
OPEN Author Correction: Extreme temperature impairs growth and productivity in a common tropical marine copepod
}

\author{
Nam X. Doan, Minh T. T. Vu, Hung Q. Pham, Mary S. Wisz, Torkel Gissel Nielsen \& \\ Khuong V. Dinh $\mathbb{D}$
}

Correction to: Scientific Reports https://doi.org/10.1038/s41598-019-40996-7, published online 14 March 2019

This Article contains a typographical error in the Methods section under subheading 'Nauplii production' where,

"The content was then filtered (mesh size $=25 \mathrm{~m}$ ) and fixed in Lugol $(4 \%)$."

should read:

“The content was then filtered (mesh size $=25 \mu \mathrm{m})$ and fixed in Lugol (4\%)."

(c) (i) Open Access This article is licensed under a Creative Commons Attribution 4.0 International License, which permits use, sharing, adaptation, distribution and reproduction in any medium or format, as long as you give appropriate credit to the original author(s) and the source, provide a link to the Creative Commons license, and indicate if changes were made. The images or other third party material in this article are included in the article's Creative Commons license, unless indicated otherwise in a credit line to the material. If material is not included in the article's Creative Commons license and your intended use is not permitted by statutory regulation or exceeds the permitted use, you will need to obtain permission directly from the copyright holder. To view a copy of this license, visit http://creativecommons.org/licenses/by/4.0/.

(C) The Author(s) 2020 